\title{
Conifers from the Cenomanian amber of Fouras (Charente-Maritime, western France)
}

\author{
Jean-David Moreau ${ }^{1, *}$, Didier Néraudeau ${ }^{2}$ and Vincent Perrichot ${ }^{2}$ \\ ${ }^{1}$ UMR CNRS 6282 Biogéosciences, Université de Bourgogne Franche-Comté, 6, boulevard Gabriel, 21000 Dijon, France \\ ${ }^{2}$ Univ. Rennes, CNRS, Géosciences Rennes-UMR 6118, 35000 Rennes, France
}

Received: 26 August 2019 / Accepted: 5 May 2020

\begin{abstract}
Fossil inclusions of arthropods and microorganisms are abundant in the Cretaceous amber from western France, but plant meso- or macroremains are scarce. Preserved remains are mostly tiny, very fragmented, and indeterminable. Only one amber locality in the Charente department has already provided conifer remains. Here, we report the first plant mesoremains ensnared in Cenomanian amber from Fouras - Bois Vert, in the Charente-Maritime department. They consist of three well-preserved leafy axes and one cone of Cheirolepidiacean conifers. Based on the helical arrangement of rhomboidal, longer than wide, and highly adpressed leaves, leafy axes are ascribed to the genus Pagiophyllum. The ovoid cone bears more than 15 imbricate, helically arranged, scale-like leaves and is ascribed to Classostrobus sp. Although Cretaceous flora is abundant in lignitic clay from the Charentes region, Pagiophyllum is reported for the first time in Albian-Cenomanian deposits from this area. Xerophytic features of Pagiophyllum further support a harsh and instable coastal environment seasonally exposed to hot, dry conditions during the mid-Cretaceous in the Charentes region.
\end{abstract}

Keywords: fossil plants / amber / Cretaceous / Pagiophyllum / xerophytic / France

\begin{abstract}
Résumé - Conifères de l'ambre cénomanien de Fouras (Charente-Maritime, Ouest de la France). Les inclusions fossiles d'arthropodes et de microorganismes sont abondantes dans l'ambre crétacé de l'Ouest de la France, mais les méso- et macrorestes végétaux sont quant à eux rares. Les restes préservés sont essentiellement minuscules, très fragmentés et indéterminables. Jusqu'ici, seule une localité du département de la Charente a livré de l'ambre contenant des conifères. Ici, nous présentons les premiers mésorestes végétaux connus dans l'ambre cénomanien de Fouras - Bois Vert, dans le département de la CharenteMaritime. Il s'agit de trois axes feuillés et d'un cône de conifère Cheirolepidiaceae bien préservés. Les axes feuillés sont attribués au genre Pagiophyllum sur la base de l'arrangement hélicoïdal de feuilles qui sont rhomboïdales, plus longues que larges et très plaquées sur les axes. Le cône est ovoïde, constitué de plus de 15 écailles arrangées de manière spiralée et est attribué à Classostrobus sp. Bien que les flores crétacées soient abondantes dans les argiles ligniteuses de la région des Charentes, Pagiophyllum est pour la première fois signalé dans les dépôts albo-cénomaniens de ce secteur. Les caractéristiques xérophytiques de Pagiophyllum sont des arguments pour soutenir que les flores du Crétacé moyen de Charente-Maritime étaient adaptées à des milieux côtiers saisonnièrement exposés à de fortes températures.
\end{abstract}

Mots clés : plantes fossiles / ambre / Crétacé / Pagiophyllum / xérophytique / France

\section{Introduction}

Plant remains such as bryophytes, conifer leafy axes, ferns, and flowers have been reported in Cretaceous amber from many localities worldwide (Chambers et al., 2010; Crepet et al., 2016; Ignatov et al., 2016; Schneider et al., 2016; Moreau et al., 2017a; Kvaček et al., 2018). However, such fossil inclusions remain

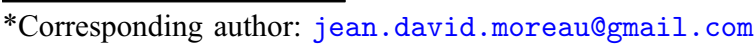

extremely rare in the French Cretaceous amber which has otherwise yielded abundant and diverse fossils of arthropods (Néraudeau et al., 2002, 2008; Nel et al., 2004; Perrichot, 2005, 2015; Perrichot et al., 2008a, 2008b, 2010), microorganisms (Breton and Tostain, 2005; Girard et al., 2009), as well as rare vertebrate integuments (Perrichot et al., 2008c; Vullo et al., 2010a). Plant meso- or macroremains found in this amber are commonly indeterminable, altered, and limited to stellate hairs (Girard, 2010), or tiny fragments of cuticle or wood sometimes 
preserved as partially empty casts (Perrichot, 2005; Girard et al., 2013). Until now, a single foliar plant remain was described in amber from La Buzinie in the Charente department (Moreau et al., 2017a). It consists of an exquisitely preserved conifer leafy axis ascribed to Glenrosa carentonensis Moreau, Néraudeau, Tafforeau \& Dépré, an extinct Cretaceous taxon characterized by an unusual stomatal arrangement inside crypts (Moreau et al., 2015). Recently, several leafy axes and a cone were discovered in the Cenomanian amber from the palaeontological site of Fouras which has hitherto provided various insect and vertebrate fossils (Néraudeau et al., 2003; Vullo et al., 2005). Here, we describe these specimens and discuss palaeoecophysiological implications.

\section{Geological setting}

The pieces of amber containing the plant remains described herein were discovered in Cretaceous deposits from the "Plage de la Vierge" at Fouras-Bois Vert in the Charente-Maritime department (western France). Regionally, the upper AlbianCenomanian series are divided into seven units, A to $G$ (Néraudeau and Moreau, 1989; Moreau, 1996; Néraudeau et al., 1997). At Fouras-Bois Vert, the deposits are exposed from subunit B1 to subunit B3 which are early Cenomanian in age based on the presence of the foraminifera Orbitolina (Conicorbitulina) conica d'Archiac in the three subunits (Néraudeau et al., 2003). Subunit B1 consists of up to $5 \mathrm{~m}$ of fossiliferous silty to sandy limestone yielding rudists (Ichthyosarcolites triangularis Desmarest), oysters (Rhynchostreon suborbiculatum Lamarck) and the foraminifera Orbitolina plana concava Lamarck. Subunit B2 corresponds to up to $5 \mathrm{~m}$ of marl and glauconitic sand. Basally, this subunit (B2ms) consists of laminated grey to lignitic clay yielding abundant wood fragments (sometimes large trunks of up to $3 \mathrm{~m}$ long), amber and vertebrate remains (Néraudeau et al., 2003; Perrichot, 2005; Vullo et al., 2005). The wood was mainly ascribed to coniferous taxa such as Agathoxylon gardoniense Crié, Brachyoxylon Hollick \& E. Jeffrey and Podocarpoxylon Gothan whereas a single specimen was ascribed to the Ginkgoalean wood Ginkgoxylon Saporta. The surface of trunks often bears marine oysters (Acutostrea lingularis Lamarck, Gyrostrea cf. delettrei Coquand) and xylophagous bivalve borings (Teredolites Leymerie). Amber from B2ms yielded various insect inclusions (Perrichot et al., 2010), among which occur some of the oldest known ants and trogossitid beetles (Perrichot et al., 2008b; Peris et al., 2014). The vertebrate remains were ascribed to terrestrial groups, such as dinosaurs (Iguanodontids; Néraudeau et al., 2003), pterosaurs (Vullo and Néraudeau, 2009) and turtles (Solemys de Lapparent de Broin \& Murelaga; Vullo et al., 2010b), as well as marine ones such as the snake Simoliophis rochebrunei Sauvage and the shark Cretodus semiplicatus Agassiz (Vullo et al., 2005, 2011).

Upper part of the subunit B2 corresponds to sandstone with accumulation of oysters (Rhynchostreon suborbiculatum, Ceratostreon flabellatum Goldfuss). The subunit B3 consists of 6-8 $\mathrm{m}$ of limestone alternating with silty to sandy marl.

\section{Material and methods}

The pieces of amber were all collected in the subunit B2 (layer B2ms). The fossiliferous amber from Fouras - Bois Vert

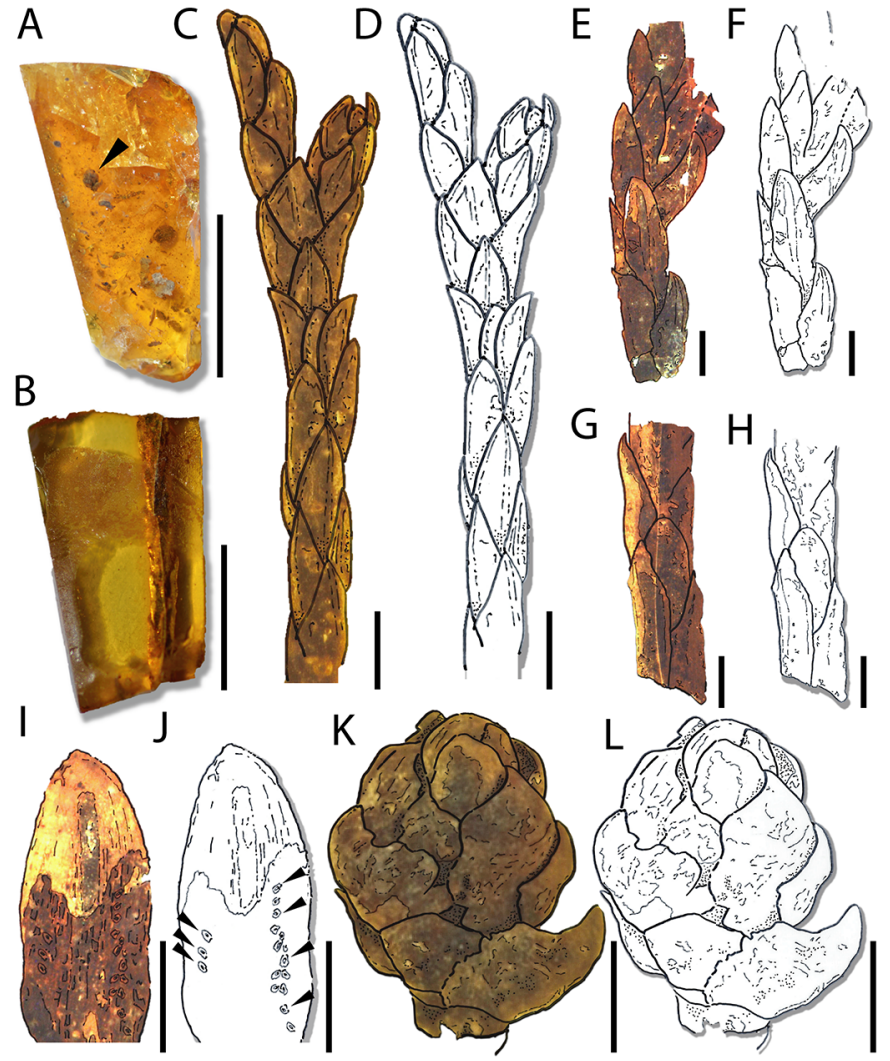

Fig. 1. Plant inclusions in Cenomanian amber from Fouras-Bois Vert. A-B. Fragment of amber bearing a conifer cone (A) and leafy axis (B); black arrow indicates location of the cone. C-H. Helically arranged conifer leafy axis, Pagiophyllum sp. I-J. Abaxial surface of a leaf showing alignment of stomatal apparatuses; black arrows indicate location of stomatal apparatuses. K-L. Cone of conifer, Classostrobus. A, K-L. IGR.FRS-7.18; B, G-H, IGR.FRS-1.14; C-D. IGR. FRS-7.25; E-F. IGR.FRS-7.10. Scale bars: $A=10 \mathrm{~mm}$; $B=5 \mathrm{~mm}$; $\mathrm{H}=1 \mathrm{~mm}$; $\mathrm{I}-\mathrm{L}=0.5 \mathrm{~mm}$.

is mostly translucent and yellow to orange (Figs. 1A and 1B). Plant remains consist of three leafy axes and one conifer cone, that were originally preserved in two amber pieces with numerous arthropod inclusions: the piece IGR.FRS-1 contained 13 hexapods; and the piece IGR.FRS-7 contained 57 arthropods (see detailed list in Cockx et al., 2016: Tab. 1). For an optimal study of each fossil inclusion, these pieces were then cut in smaller fragments using scalpel blades, and each fragment was polished using silicon carbide papers on a Buehler Metaserv 3000 polisher. The conifer remains are preserved in three dimensions and show an exquisite preservation of the cuticle including stomatal apparatuses. Photographs were taken with a BMS digital USB camera (5 megapixels) mounted on a stereomicroscope Leica 125. The specimens presented in this paper are housed at the Geological Department and Museum of the University of Rennes 1.

\section{Systematic palaeobotany}

Order-Coniferales

Family-Cheirolepidiaceae 


\subsection{Leafy axes}

Genus - Pagiophyllum Heer, emend. Harris, 1979

Pagiophyllum sp.

Figs. 1C-1J

Material. 3 specimens; IGR.FRS-7.10, IGR.FRS-1.14, IGR.FRS-7.25.

Description. Leafy axes are straight (Figs. 1C, 1D, 1G, 1H) to slightly curved (Figs. 1E and 1F). The largest specimen is $10 \mathrm{~mm}$ long. Shoots are narrow and up to $1.5 \mathrm{~mm}$ in diameter. Leaves are persistent, helically arranged (phyllotaxy 3/8), highly adpressed and imbricated (Figs. $1 \mathrm{C}-1 \mathrm{H}$ ). Leaves are scale-like, rhomboidal, longer than wide, and keeled on abaxial side (Figs. 1C-1J). They are $1.7-2.5 \mathrm{~mm}$ long and $0.6-0.8 \mathrm{~mm}$ wide. Apically, leaves display a free part which is up to $0.8 \mathrm{~mm}$ long. The abaxial surface of leaves is convex whereas adaxial surface is concave. The leaf margin is entire and the shape of the leaf apex is quite pointed. Surface of leaves locally shows the outlines of epidermal cells. On the abaxial surface, stomatal apparatuses are arranged in longitudinal rows that converge toward the leaf apex (Figs. 1I and 1J). Stomatal apparatuses on the abaxial surface are 50-70 $\mu \mathrm{m}$ long and 35-45 $\mu \mathrm{m}$ wide. Stomatal rows are not sunken but guard cells of individual stomata are sunken in a pit. Pit apertures are mainly oval, and sometimes circular. Their orientation is quite stable, mainly oriented transversally to the leaf margin. However, they are sometimes oriented obliquely to leaf margin. Subsidiary cells form a thick and well-marked rim around the pit apertures. Abaxial surface of leaves partially shows the shape of ordinary epidermal cells which are rectangular and form longitudinal rows, that are oriented parallel to the leaf axis.

Remarks. The gross morphology of Pagiophyllum is close to those of the leafy axis Brachyphyllum Brongn. (e.g. straight twigs having needles helically arranged and small leaves). Harris (1979) highlighted the difficulty to distinguish both genera and proposed that the "sole distinction of Pagiophyllum from Brachyphyllum is its longer free leaf". He specified in the emended diagnoses of Brachyphyllum and Pagiophyllum "leaf composed of a basal cushion tapering into a small free part, length of free part (upper surface beyond leaf cushion) or total height of leaf and cushion (outward from shoot) less than width of leaf cushion" for the first, whereas "leaf about as broad as its basal cushion, length exceeding width of cushion" for the second. Brachyphyllum was reported from many Cretaceous palaeobotanical sites of western France (e.g. Coquand, 1860; Gomez et al., 2008; Néraudeau et al., 2009; Moreau et al., 2014a). It differs from Pagiophyllum by its leaves that are as long as wide, with a shorter free part strongly appressed to the stem. Following Harris (1979), the specimens from Fouras can be confidently ascribed to Pagiophyllum.

\subsection{Cone}

Genus-Classostrobus Alvin, Spicer \& J. Watson 1978 Classostrobus sp.

Figs. $1 \mathrm{~K}$ and $1 \mathrm{~L}$

Material. 1 specimen; IGR.FRS-7.18

Description. Cone is ovoid, $1.7 \mathrm{~mm}$ long, $1.3 \mathrm{~mm}$ wide and bears more than 15 imbricate, helically arranged, scale-like leaves. The scale-like leaves are convex, rhomboidal in shape, and show acuminate or acute apices (Figs. 1K and 1L). They are up to $0.8 \mathrm{~mm}$ long and up to $0.7 \mathrm{~mm}$ wide.

Remarks. Inner structures of the cone are not visible. We may notice that tiny male cones ascribed to Classostrobus $\mathrm{sp}$. and showing a gross morphology close to the specimen from Fouras-Bois Vert were discovered in Cenomanian lignitic clay from several areas of Charente-Maritime (e.g. Aix Island, Néraudeau et al., 2009; Puy-Puy, Perrichot, 2005). Pagiophyllum and Classostrobus often co-occur in Mesozoic plant beds (Thévenard, 1993; Van Konijnenburg-Van Cittert, 1987). However, stomatal apparatuses being not visible, the cone from Fouras-Bois Vert cannot be confidently linked with the leafy axis Pagiophyllum described below.

\section{Discussion and conclusions}

Albian-Cenomanian plant remains have been reported from many localities in western France (e.g. Coquand, 1860; Zeiller, 1887; Lecointre and Carpentier, 1938; Pons et al., 1976; Pons, 1979; Koeniguer, 1981; Berthelin and Pons, 1999; Néraudeau et al., 2002, 2005, 2013, 2020; Gomez et al., 2004, 2008; Coiffard et al., 2009; Saint-Martin et al., 2013; Moreau et al., 2014a, 2014b, 2015, 2017b, 2017c; Valentin et al., 2014; Fleury et al., 2017). These reports included angiosperms, conifers, bennettitaleans, ferns, cycads and ginkgophytes. Conifers are represented by leafy axes, male cones, as well as isolated ovuliferous scales. Leafy axes of Brachyphyllum, Frenelopsis (Schenk) emend. J. Watson, Geinitzia Endl., and Glenrosa J. Watson \& H.L. Fisher are abundant in most of conifer-dominated assemblages from the Cretaceous deposits of Charente-Maritime (e.g. Gomez et al., 2008; Néraudeau et al., 2009; Moreau et al., 2014a, 2015, 2017c). However, the conifer Pagiophyllum is reported for the first time from this area, as it was hitherto known only from the Cenomanian deposits of the Vienne department (Valentin et al., 2014).

Conifers with xerophytic characters have already been found among the Cretaceous coastal flora of western France (e. g. Brachyphyllum, Frenelopsis, and Glenrosa; Gomez et al., 2008; Moreau et al., 2015). According to these studies, these plants were adapted to withstand intense sunlight and coastal environments exposed to desiccant conditions coupled with saline sea water, and dry conditions. Pagiophyllum clearly shows fleshy shoots, small leaves pressed against the axis, thick cuticle, and sunken stomata apparatuses with subsidiary cells forming a thick rim. These features are those of a flora in a tropical climate with contrasted seasons cyclically dry (Thévenard et al., 2003). In accordance with this hypothesis, Néraudeau et al. (2003) interpreted the amber-bearing bed from Fouras as a paralic deposit showing both marine and terrestrial imputs. Complementing previous palaeobotanical analyses (e.g., Gomez et al., 2008; Moreau et al., 2015), the xerophytic features of Pagiophyllum are new arguments to support that Albian-Cenomanian coastal floras of CharenteMaritime were well-adapted to paralic environments seasonally exposed to hot, dry conditions.

The Cretaceous flora from western France is mostly preserved as impressions and compressions with or without cuticle in clayey and lignitic deposits. By contrast with these highly compressed fossil plants, the Pagiophyllum leafy axes and the cone from the Fouras amber are preserved in three 
dimensions. Moreau et al. (2017a, 2017b, 2017c) demonstrated that some specimens can exquisitely preserved most of the tissues, including epidermis, palisade parenchyma, spongy parenchyma, transfusion tracheids and vascular bundles. However, the inner structures of the specimens from Fouras cannot be explored using classic light microcopy. Although we cannot ensure such preservation, future investigations using 3D imaging technique such as synchrotron tomography should be appropriate to explore the histology of these specimens from Fouras.

Acknowledgements. We thank Eric Dépré (INRA Surgères), Vincent Girard (Université de Montpellier) and Romain Vullo (Université Rennes 1) for their contributions during several field trips at Fouras. We thank the two anonymous reviewers for their constructive comments on the manuscript. This work is a contribution to the research program INSU TELLUS InterrVie, Project NOVAMBRE 2 (coord. D. Néraudeau and V. Perrichot).

\section{References}

Berthelin M, Pons D. 1999. Signification des caractères partagés entre Bennettitales et Cycadales. Implications de la découverte d'une Cycadale nouvelle du Cénomanien de l'Anjou (France). Annales de Paléontologie 85: 227-239.

Breton G, Tostain F. 2005. Les microorganismes de l'ambre cénomanien d'Écommoy (Sarthe, France). Comptes Rendus Palevol 4: 31-46.

Chambers KL, Poinar Jr GO, Buckley R. 2010. Tropidogyne, a new genus of Early Cretaceous Eudicots (Angiospermae) from Burmese amber. Novon 20: 23-29.

Cockx PFD, McKellar RC, Perrichot V. 2016. First records of the subfamilies Bethylinae (Hymenoptera: Bethylidae) and Cleptinae (Hymenoptera: Chrysididae) in Upper Cretaceous amber from France. Cretaceous Research 68: 1-8.

Coiffard C, Gomez B, Thiébaut M, Kvaček J, Thévenard F, Néraudeau D. 2009. Eucalyptolaurus depreii, gen. et sp. nov., intra-marginal veined Lauraceae leaves from the Albian-Cenomanian of Charente-Maritime (Western France). Palaeontology 52: 323-336.

Coquand H. 1860. Synopsis des animaux et des végétaux fossiles observés dans les formations secondaires de la Charente, de la Charente Inférieure et de la Dordogne. Marseille : Barlatier-Feissat et Demonchy.

Crepet WL, Nixon KC, Grimaldi D, Riccio M. 2016. A mosaic Lauralean flower from the Early Cretaceous of Myanmar. American Journal of Botany 103: 290-297.

Fleury R, Polette F, Batten DJ, Durand M, Moreau J-D, Néraudeau D, et al. 2017. Palaeobotanical investigation of a Cenomanian clay lens in Hucheloup Quarry, Maine-et-Loire, NW France: Taxonomic, stratigraphic and palaeoenvironmental implications. Annales de Paléontologie 103: 235-250.

Girard V. 2010. Microcénoses des ambres médio-crétacés français. Taphonomie, systématique, paléoécologie et reconstitution du paléoenvironnement. Mémoires de Géosciences Rennes 134: $1-294$.

Girard V, Schmidt AR, Struwe S, Perrichot V, Breton G, Néraudeau D. 2009. Taphonomy and palaeoecology of mid-Cretaceous amber preserved microorganisms from southwestern France. Geodiversitas 31: 152-163.
Girard V, Néraudeau D, Breton G, Morel N. 2013. Palaeoecology of the Cenomanian amber forest of Sarthe (western France). Geologica Acta 11: 321-330.

Gomez B, Daviero-Gomez V, Perrichot V, Thévenard F, Coiffard C, Philippe M, et al. 2004. Assemblages floristiques de l'AlbienCénomanien de Charente-Maritime (SO France). Annales de Paléontologie 90: 147-159.

Gomez B, Coiffard C, Dépré E, Daviero-Gomez V, Néraudeau D. 2008. Diversity and histology of a plant litter bed from the Cenomanian of Archingeay-Les Nouillers (SW France). Comptes Rendus Palevol 7: 135-144.

Harris TM. 1979. The Yorkshire Jurassic Flora, V, Coniferales. London (UK): British Museum.

Ignatov MS, Heinrichs J, Schäfer-Verwimp A, Perkovsky EE. 2016. The first record of a bryophyte in Upper Cretaceous amber from Taimyr, northern Siberia: Taimyrobryum martynoviorum gen. et sp. nov. (Bryopsida). Cretaceous Research 65: 25-31.

Koeniguer J-C. 1981. Les milieux forestiers littoraux du Cénomanien inférieur des Charentes. Cretaceous Research 2: 351-352.

Kvaček J, Barrón E, Heřmanová Z, Mendes MM, Karch J, Žemlička J, et al. 2018. Araucarian conifer from late Albian amber of northern Spain. Palaeontology 4: 643-656.

Lecointre G, Carpentier A. 1938. Sur les empreintes de Frenelopsis $\mathrm{du}$ Cénomanien provenant du forage de Monts-sur-Guesnes (Vienne). Bulletin de la Société géologique de France 5: 583-586.

Moreau J-D, Néraudeau D, Gomez B, Tafforeau P, Dépré E. 2014a. Plant inclusions from the Cenomanian flints of Archingeay-Les Nouillers, western France. Lethaia 47: 313-322.

Moreau J-D, Néraudeau D, Gomez B, Tafforeau P, Dépré E. 2014b. Inclusions of conifers, echinoids, foraminifers and sponges in flints from the Cenomanian of Charente-Maritime (France): contribution of synchrotron microtomography. Comptes Rendus Palevol 13: 455-461.

Moreau J-D, Néraudeau D, Tafforeau P, Dépré E. 2015. Study of the histology of leafy axes and male cones of Glenrosa carentonensis sp. nov. (Cenomanian Flints of Charente-Maritime, France) using synchrotron microtomography linked with palaeoecology. PLoS One 10(8): e0134515.

Moreau J-D, Néraudeau D, Perrichot V, Tafforeau P. 2017a. 100million-year-old conifer tissues from the mid-Cretaceous amber of Charente (western France) revealed by synchrotron microtomography. Annals of Botany 119: 117-118.

Moreau J-D, Néraudeau D, Tafforeau P, Dépré E. 2017b. Synthèse sur la diversité des préservations végétales du site d'Archingeay-Les Nouillers (France) : un Konservat-Lagerstätte pour les flores de l'Albien-Cénomanien. Annales de Paléontologie 103: 165-171.

Moreau J-D, Néraudeau D, Philippe M, Dépré E. 2017c. Albian flora from Archingeay-Les Nouillers (Charente-Maritime): comparison and synthesis of Cretaceous meso-and macro-remains from the Aquitaine Basin (southwestern France). Geodiversitas 39: 729-741.

Moreau P. 1996. Analyse de la transgression cénomanienne sur la bordure nord-occidentale du Bassin de l'Aquitaine. Géologie de la France 1: 3-16.

Nel A, Perrault G, Perrichot V, Néraudeau D. 2004. The oldest ant in the Lower Cretaceous amber of Charente-Maritime (SW France) (Insecta: Hymenoptera: Formicidae). Geologica Acta 2: 23-29.

Néraudeau D, Moreau P. 1989. Paléoécologie et paléobiogéographie des faunes d'échinides du Cénomanien nord-aquitain (CharenteMaritime, France). Geobios 22: 293-324.

Néraudeau D, Thierry J, Moreau P. 1997. Variations of echinoids biodiversity during the Cenomanian-Early Turonian transgressive 
episode in the Charente (France). Bulletin de la Société Géologique de France 168: 51-61.

Néraudeau D, Perrichot V, Dejax J, Masure E, Nel A, Philippe M, et al. 2002. Un nouveau gisement à ambre insectifère et à végétaux (Albien terminal probable): Archingeay (Charente-Maritime, France). Geobios 35: 233-240.

Néraudeau D, Allain R, Perrichot V, Videt B, de Lapparent de Broin F, Guillocheau F, et al. 2003. Découverte d'un dépôt paralique à bois fossiles, ambre insectifère et restes d'Iguanodontidae (Dinosauria, Ornithopoda) dans le Cénomanien inférieur de Fouras (CharenteMaritime, Sud-Ouest de la France). Comptes Rendus Palevol 2: 221-230.

Néraudeau D, Vullo R, Gomez B, Perrichot V, Videt B. 2005. Stratigraphie et Paléontologie (plantes, vertébrés) de la série paralique Albien terminal-Cénomanien basal de Tonnay-Charente (Charente-Maritime, France). Comptes Rendus Palevol 4: 79-93.

Néraudeau D, Perrichot V, Colin J-P, Girard V, Gomez B, Guillocheau $\mathrm{F}$, et al. 2008. A new amber deposit from the Cretaceous (uppermost Albian-lowermost Cenomanian) of southwestern France. Cretaceous Research 29: 925-929.

Néraudeau D, Vullo R, Gomez B, Girard V, Lak M, Videt B, et al. 2009. Amber, plant and vertebrate fossils from Lower Cenomanian paralic facies of Aix Island (Charente-Maritime, SW France). Geodiversitas 31: 13-27.

Néraudeau D, Redois F, Ballèvre M, Duplessis B, Girard V, Gomez B, et al. 2013. L'ambre cénomanien d'Anjou: stratigraphie et paléontologie des carrières du Brouillard et de Hucheloup (Ecouflant, Maine-et-Loire). Annales de Paléontologie 99: 361-374.

Néraudeau D, Vullo R, Bénéfice P, Breton G, Dépré E, Gaspard D, et al. 2020. The paralic Albian-Cenomanian Puy-Puy Lagerstätte (Aquitaine Basin, France): an overview and new data. Cretaceous Research 111: 104124.

Peris D, Kolibáč J, Delclòs X. 2014. Cretamerus vulloi gen. et sp. nov., the oldest bark-gnawing beetle (Coleoptera: Trogossitidae) from Cretaceous amber. Journal of Systematic Palaeontology 12: 879-891.

Perrichot V. 2005. Environnements paraliques à ambre et à végétaux au Crétacé nord-aquitain (Charentes, Sud-Ouest de la France). Mémoires de Géosciences Rennes 118: 1-310.

Perrichot V. 2015. A new species of Baikuris (Hymenoptera: Formicidae: Sphecomyrminae) in mid-Cretaceous amber from France. Cretaceous Research 52: 585-590.

Perrichot V, Lacau S, Néraudeau D, Nel A. 2008a. Fossil evidence for the early ant evolution. Naturwissenschaften 95: 85-90.

Perrichot V, Nel A, Néraudeau D, Lacau S, Guyot T. 2008b. New fossil ants in French Cretaceous amber (Hymenoptera: Formicidae). Naturwissenschaften 95: 91-97.

Perrichot V, Marion L, Néraudeau D, Vullo R, Tafforeau P. 2008c. The early evolution of feathers: fossil evidence from Cretaceous amber of France. Proceeding of the Royal Society of London, Biological Sciences 275: 1197-1202.

Perrichot V, Néraudeau D, Tafforeau P. 2010. Charentese amber. In: Penney D, ed. Biodiversity of fossils in amber from the major world deposits. Manchester (UK): Siri Scientific Press, pp. 192-207.

Pons D. 1979. Les organes reproducteurs de Frenelopsis alata (K. Feistm) Knobloch, Cheirolepidiaceae du Cénomanien de l'Anjou, France. Comptes Rendus du 104ème Congrès national des Société savantes, Bordeaux, Section Sciences 209-231.

Pons D, Boureau E, Broutin J. 1976. Nouvelles études paléobotaniques des environs d'Angers I. Eretmophyllum andegavense nov. sp., Ginkgoale fossile du Cénomanien. In: Comptes Rendus du $97^{e}$ Congrès national des Sociétés savantes, Section Sciences, Nantes, pp. 367-369.

Saint-Martin J-P, Saint-Martin S, Néraudeau D. 2013. L'ambre associé aux lignites cénomaniens du Sarladais (Dordogne, SO France). Annales de Paléontologie 99: 289-300.

Schneider H, Schmidt AR, Heinrichs J. 2016. Burmese amber fossils bridge the gap in the Cretaceous record of polypod ferns. Perspectives in Plant Ecology, Evolution and Systematics 18: 70-78.

Thévenard, F. 1993. Les coniférales du Jurassique inférieur du gisement de Chadelcoste, basin des Causses (Lozère, France). Review of Palaeobotany and Palynology 78: 145-166.

Thévenard F, Deschamps S, Guignard G, Gomez B. 2003. Les plantes fossiles du gisement hettangien de Talmont-Saint-Hilaire (Vendée, France). Le Naturaliste vendéen 3: 69-87.

Valentin X, Gomez B, Daviero-Gomez V, Charbonnier S, Ferchaud P, Kirejtshuk A, et al. 2014. Plant-dominated assemblage and invertebrates from the Lower Cenomanian of Jaunay-Clan, southwestern France. Comptes Rendus Palevol 13: 443-454.

Van Konijnenburg-Van Cittert JH. 1987. New data on Pagiophyllum maculosum Kendall and its male cone from the Jurassic of North Yorkshire. Review of palaeobotany and palynology 51: 95-105.

Vullo R, Néraudeau D. 2009. Pterosaur remains from the Cenomanian (Late Cretaceous) paralic deposits of Charentes, western France. Journal of Vertebrate Paleontology 29: 277-282.

Vullo R, Néraudeau D, Allain R, Cappetta H. 2005. Un nouveau gisement à microrestes de vertébrés continentaux et littoraux dans le Cénomanien inférieur de Fouras (Charente-Maritime, Sud-Ouest de la France). Comptes Rendus Palevol 4: 95-107.

Vullo R, Girard V, Azar D, Néraudeau D. 2010a. Mammalian hair in Early Cretaceous amber. Naturwissenschaften 97: 683-687.

Vullo R, Lapparent De Broin F, Néraudeau D, Durrieu N. 2010b. Turtles from the Early Cenomanian paralic deposits (Late Cretaceous) of Charentes, France. Oryctos 9: 37-48.

Vullo R, Rage JC, Néraudeau D. 2011. Anurian and squamate remains from the Cenomanian (Late Cretaceous) of Charentes, western France. Journal of Vertebrate Paleontology 31: 279-291.

Zeiller R. 1887. Note sur la flore des lignites de Simeyrols. Bulletin de la Société géologique de France 15: 882-884.

Cite this article as: Moreau J-D, Néraudeau D, Perrichot V. 2020. Conifers from the Cenomanian amber of Fouras (Charente-Maritime, western France), BSGF - Earth Sciences Bulletin 191: 16. 